\title{
Global Economic Meltdown and Nigeria's Dependent Political Economy: A Litmus Test
}

\author{
Salihu Mohammed Niworu ${ }^{1}$ \\ ${ }^{1}$ Political Science Department, Faculty of Management \& Social Sciences, Ibrahim Badamasi Babangida \\ University, Lapai, Nigeria \\ Correspondence: Salihu Mohammed Niworu, Political Science Department, Faculty of Management \& Social \\ Sciences, Ibrahim Badamasi Babangida University, Lapai, Niger State, Nigeria. Tel: 234-803-598-3879 E-mail: \\ smniworu2120@yahoo.com
}

Received: March 29, 2012 Accepted: June 1, 2012 Online Published: September 20, 2012

doi:10.5539/ass.v8n12p216 URL: http://dx.doi.org/10.5539/ass.v8n12p216

\begin{abstract}
Dependency entails structural linkages between two countries particularly developed and under developed to the extend that the periphery is always awakened from its slumber by the internal dynamics of the center. The internal workings of the periphery are as usual the reflection of the center. This is the situation of Nigeria with viable economic potentials for diversification with the resultant effects of development. But unfortunately, the nation still remains a mono cultural economy with a significant number of her citizens employed in the extractive industry. Since the primary sector of the economy is the largest employer of labour and exchange of the primary product is determined by the forces of demand and supply in the international market, the global economic meltdown would therefore have a devastating economic hardship on Nigerians because virtually all consumables from the secondary and tertiary sectors of the economy are imported into the country. This paper therefore looks at the implications of dependency in the face of global economic meltdown on Nigeria and suggests that a wholesome investment in human capital development to enhance the tertiary sector of the economy should be encouraged.
\end{abstract}

Keywords: primary production, inept leadership, market failure, diversification, national prosperity

\section{Introduction}

Security and development are two important concepts in the survival and sustenance of any given political economy. Nigeria cannot in this regard be an exception in the quest for these dual concepts in her body politics. Consequently, amidst her checkered political history, the military and their subsequent circulation to the "civilianized military" ruling elite made several attempts to forge the country ahead with multiple socio economic and political reforms or what can be termed as national philosophy or guiding principles. The whole idea is to empower Nigerians in all spheres of life as encapsulated by chapter two of the 1999 Nigerian constitution, Section 4(2) which stated that (a) - Sovereignty belongs to the people of Nigeria from whom Government through this constitution derives all its powers and authority. (b) -The security and welfare of the people shall be the primary purpose of government. Essentially, the legitimacy of government emanating from the wishes of the people is not meant to aid and abet excessive looting of public treasuries. It is rather meant to facilitate the development of the economy for social, economic and political security. Section 16(1-2) of the same chapter two of 1999 constitution was categorical on Nigerian economy that the state shall:

A. Harness the resources of the nation and promote national prosperity, efficient, dynamic and self reliant economy.

B. Control the national economy in such a manner as to secure the maximum welfare, freedom and happiness of every citizen on the basis of social justice and equality of status and opportunity.

C. To promote a planned and balanced economic development

D. That the economic system is not operated in such a manner as to permit the concentration of wealth or the means of production and exchange in the hands of few individuals or group.

E That suitable and adequate shelter, suitable and adequate food, reasonable national minimum living wages, old age care and pensions, unemployment and sick benefits and welfare of the disabled are provided for all 
citizens.

It is in consonance with these constitutional provisions that Jega (2009) acknowledged the aspirations and strenuous struggles of Nigerians for regime change from military to civilian rule with several degrees of sacrifices and hopes for the satisfaction of their basic needs of food, security, education, health, employment, and infrastructure and service delivery. A significant percentage of these basic needs eluded Nigerians because the economy is mono-cultural and controlled by small elite group or what may be rightly called commission agents of the international economic and financial agencies

To further perpetuate itself in power and continue its dominance in the control of the coercive instrument of the state, the ruling elites made the state depend greatly on external influence on major decisions of national importance and the provision of critical infrastructure. In the same vein, the periphery of periphery depends on the center of periphery for expansion and sustenance. This is glaringly seen in the recent lexicon popularized in the Nigerian political scene called joint account. Khor (2003) is of the opinion that there is a rapid erosion of national sovereignty with the resultant effect of narrowing down the ability of government and people to make choice from options in economic, social and cultural policies.

\section{Research Problem}

The iniquity and inept leadership that bequeathed Nigeria has further open up out-lets for foreign intrusion into the political economy with more finished consumables proliferating the Nigerian markets and streets with a large amount of capital flight to foreign banks. This in essence entrenched a structural linkage that has negative impact on the Nigerian economy. While the advanced capitalist nations gave subsidies to their large industrial conglomerates, cut down interest rate to devalue foreign currency held in their banks with an attempt to lure another chunk of money outside their shores into their financial system (Gadu, 2009), the Nigerian political economy waited to be stimulated from outside on what measures to be taken to forestall the global economic meltdown and subsequently cushion its effect on the citizenry.

This paper therefore sets out to address the centrality of the state in the production of one primary product (oil) perpetuated by an insignificant number of ruling elite group at the detriment of the masses thereby making the entire political economy dependent on foreign influence. It is also incumbent upon this paper to address the implications of global economic meltdown on the security and development of Nigeria.

\section{Theoretical and Conceptual Framework}

Essentially, a theory is a set of ideas that intends to explain a given phenomenon or why some thing happened or existed. In the purview of social sciences, it is an attempt to gain intuitive insight of social behaviors, institutions, political systems and cultures through marshalling of factual, historical and political events in such a way that the reader will have the experience of understanding. It is on this basis that this paper utilized globalization and dependency theories. The former as envisaged by Giddens (2000) is capable of enhancing interconnectedness and networks necessary for investment capital to move across the globe freely. While the latter is predicated on the fact that dependence on foreign capital, technology and expertise impede economic development of the peripheral countries. Therefore global economic meltdown is an extension of the negative consequences of capitalism to the noncore nations of the world (http://encarta.msn.com).

Conceptually, dependency is an attempt to explain the impact of imperialism on the peripheral countries and their development prospects. It also considers the global accumulation process as the main determinant of under development. The underdevelopment theories (UDT) in the ranks of Emmanuel Aghiri, Ander Gunder Frank, Samir Amir e.t.c. in the 1960 s through 1970s argued that colonial domination had produced relationships between the developed and the developing world that were inherently unequal. They stressed further that without the restructuring of the international economy, the former colonial countries would find it virtually difficult to delink from their subordinate position and experience true growth and development. Offiong (1980) opined that:

Dependency simply states that crucial economic decisions are made not by the countries that are being developed, but by foreigners whose interest are carefully safeguarded. Foreigners use their economic power to buy political power in the countries that they penetrate. This could mean political pressure by the imperialist metropolis or even military intervention. This collusion between alien economic and political power distort both the economy and the policy of the dependent countries. Out of this situation emerge political alliance between the domestic and foreign bourgeoisie.

Parting from the above, Santos (1970), configures dependency as a situation in which the economy of certain countries is conditioned by the development and expansion of another economy to which the former is subjected. 
In this situation while the advanced capitalist nations can expand and be self sustaining, the peripheral nations of the third world do this only as a reflection of what is happening in the capitalist core countries which may have positive or negative effect on their economic development.

The negativity of dependency can clearly be seen as the global economic meltdown gradually unfold and permeate to ex-colonial countries. This has re-enforces the conception of Caporaso on dependency when he said it is a process of incorporating the less developed counties into global capitalist system and the structural distortion resulting there from (Caporaso, 1978)

\section{Analysis and Discussion of Result}

With the integration of economic, political and cultural systems across the world in what the imperialist termed as globalization, Nigeria has been entangled in her quest for economic development. This is consequent upon the refusal of a significant number of her post independence political class to sincerely diversify the economy and eventually delink from perpetual dependence and obnoxious structural linkages. Instead, they maintained selfish alliances with the metropolitan centers to further strengthen primitive capital accumulation and exploitation of the peasantry. Offiong (1980) rightly stated that the process is now completed because just as the metropolis exploits the colonies, so does the domestic colonial bourgeois class exploits the rest of the population.

In view of the above, the consequences of global economic meltdown would have been mild if the political class since independence invests the huge resources of the nation in human capital development with an enabling environment that can further develop the tertiary sector of the economy. A sector that would produce intellectuals and skilled personnel that can rightly place the nation on the path of industrialization where automation substitutes manual and energy sapping methods of production.

It is of paramount importance to note that America, Britain, France and other capitalist nations where global economic crisis emanated from are enjoying postindustrial benefits, Nigeria and Africa at large remain poverty stricken, backward and underdeveloped largely because of selfish tendencies. Ayittey (2002) commented that African's woes are designed and perpetuated by architects that are indigenous to Africa. He stressed further that the political class indulge in high level corruption leading to sit tight syndrome, bad governance, capital flight, economic mismanagement, lack of investment in productive ventures, infrastructural decay, fetish practices, civil wars, selective justice and flagrant violation of rule of law, unconstitutional change of government by the military and the thieving of peoples mandate by the civilian political elite.

Significantly, Nigeria's natural endowment has no bound both human and material. It is against this backdrop that Obasi (1989:5) stated that:

Nigeria is richly blessed with a wide variety of mineral resources. This include (1) fossil fuels e.g petroleum, lignite, coal, oil shale, tar sand and natural gas. (2) Metallic minerals e.g tin, iron-ore, lead zinc, columbite, uranium and gold (3) industrial minerals e.g limestone, marble, clays, rock salt, phosphate. The food crops include yam, cassava, maize, rice, cow pea, millet rice, beans and wheat, cocoa, cotton, groundnut, rubber, soya beans, groundnut oil, palm oil, palm kernel and bennis seed.

Given these gifts of nature with human population of about one hundred and sixty million people $(160,000,000)$, multinational corporations of America, Europe and Asia have taken this advantage and created national bourgeoisie and compradors to sustain their dominance. Their influence is felt in all sectors of the Nigerian economy. With neoliberal reforms in the economy, the Briton wood institutions have introduced public private partnership (ppp) as a new lexicon. At this instance the political class crookedly acquired public properties and partners with the multinationals in all sectors of the economy. They are into manufacturing, building, construction, distribution, transport, communication, aviation, oil and gas.

To buttress this further, Habu Mohammed (2007) configures the connivance of the national bourgeoisie and their comprador cabals at the detriment of national interest, which prepared fertile ground for dependency. He said that:

The Transco company bought 51 percent share holding in Hilton Hotel, now Transco Hilton Hotel, Abuja and 75 percent shares in NITEL despite the fact that only 51 percent shares of the company were advertised.

Given this background, the domestic market of Nigeria became flooded with imported consumables that could be locally produced given the enabling environment. Consequently, Nigeria became affected by the global economic crisis. According to Stieglitz (2009), these crises which was supposed to help in diffusing the risk, however, it has enabled the failure of America to permeate the world like a contagious disease with devastating 
effect on the poor countries.

On the other hand, Gadu (2009) is of the view that Nigeria who has no industrial nor financial power is already feeling the negative consequences of liberal economic policies pursued by America, Britain and France. In the shortest term, the value of Nigeria foreign reserve held in foreign currency and in foreign banks has been on a free fall. The naira continues to crash against major currencies and the price of crude oil has been on a downward slide. This cut in revenue has impacted negatively on government budgetary allocations that the foreign reserves have to be plugged back to augments the budget.

Gadu stressed further that in the long run, Nigeria will be left in the search for alternative source of energy developed by the western powers with the resultant effect of financial, economic and strategic implications to the country because at that point in time the income from oil would have reduced drastically.

\section{Conclusion}

Global economic meltdown is a consequence of market failure attributable largely to gross fiscal indiscipline in the classical economic policies of America and Western Europe. Market mechanisms have failed to create enabling environment for individuals particularly in the third world countries of Africa to realize their highest level of want satisfaction given their individual endowment. While the American financial sector gave excessive loan to her private business establishments that resulted to global financial crisis, Nigerian banking sector placed stringent conditions with highest interest rate with national and comprador bourgeoisies as the only beneficiaries while the peasant masses in the extractive industry, petty trading and public servants were left at the mercy of monthly salary.

The enormous wealth of the nation that accrues from oil is optimally enjoyed by 1 insignificant number of the ruling elite whose control of the coercive instrument of the state consolidated their position and impoverished mass of people with bleak future. The lower echelon of the society grappled with inadequate and ineffective health facilities, poor housing, clothing, ignorance, malnourishment, infant mortality and morbidity while the upper echelon continue to maintain link with the metropolis facilitating dependent relationship and its reflection glaringly manifested in the administration of the structural divisions of the Nigerian State.

With these center peripheral linkages the implication of the global economic meltdown on Nigerian political economy is devastating. In the short run, there is budget deficit affecting the social responsibilities of the government. The prices of consumables are sky-rocking resulting from the global financial crisis. The worst of all people are likely to lose their jobs, which will create serious social problems in the society. Oil as a non-replenish able resource might come to an end, which will warrant the search for an alternative source of energy outside the shores of Nigeria with great financial and strategic consequences on Nigeria.

\section{Recommendations}

With the failure of market mechanism to provide welfare services to all classes of the society, there is a great need for paradigm shift from deregulated free market economy to a regulated economy with relative degree of autonomy. This paper is an apologist of neo-classical political economic theorist inclination on the provision of public goods or collective consumption goods. These goods fall within the category of education, safe road network, property right, leadership, health, constitutional regime change based on social acceptance of the electorates, research and development.

The political class assuming public offices periodically should delink from total dependence on the metropolitan centers and their guided institutions of Briton wood in taking political and economic decisions for the country.

They should desist from primitive capital accumulation and place the nation on the pedestal for industrialization with the aim of transition to a knowledge, scientific and technologically based industrial society.

America and other western powers should be more sincere in articulating the third world countries of Africa in global capitalism by making the acquisition of the technical knowledge possible for the third world in all partnership.

\section{References}

Ayittey, G. B. N. (2002). Sustainable Development: Promoting Progress or Perpetuating Poverty? London: Profile Books.

Caporaso, J. (1978). Dependence and Dependency in the Global System. International Organization, 32.

Federal Republic of Nigeria. (1999). Constitution of the Federal Republic of Nigeria. Lagos Government Press.

Gadu, L. I. (2009). The Global Economic Meltdown: A Nigeria that can say no. Retrieved from 
http://www.triumphenewspaper.com

Giddens, A. (2000). The Globalizing of Modernity. In Held, D., \& McGrew, A. (Eds.), The Global Transformation Reader: An introduction to the Globalization Debate. Cambridge: Polity Press.

Jega, A. M. (2009, May 18-20). A Decade of Transition to Democracy (1999-2009): Reflections on Nigeria's Fourth Republic, A keynote address Delivered at the National Conference organized by the Department of History and Archeology. IBB University, Lapai.

Khor, M. (2003). Globalization and south: Some critical issues. Abuja.

Mohammed, H. (2007, August 21-24). Democratization in the face of Neo, Liberal Reforms in Nigeria's public Enterprises: A Disempowerment or Fair Dividend. A paper presented at the $21^{\text {st }}$ Annual Conference of the Nigeria political science Association. Bayero University, Kano.

Obasi, I. N. (1989). The Domestic Dimensions of the Nigerian Economy 1960-86, in Nigeria International Economic Relations Nigerian Institute of international Affairs. Victor Island, Lagos.

Offiong, D. A. (1980). Imperialism and Dependency Enugu. Fourth Dimension Publishing Co.

Santos, D. (1970). The Structure of Dependence American. Economic Review, Lx.

Stigliz, J. (2009). Global Financial Crisis. Retrieved from http://www.globalissues.org/article/768/global-financial-crisis 